\title{
Pharmaceutical Evaluation of Vidangadi Lepaguti An Ayurvedic Topical Formulation
}

\author{
Research Article
}

\section{Mangesh Dhote $^{*}$, Bharat Rathi², Rita Dongre ${ }^{3}$}

\author{
1. PG scholar, 2. Professor, Department of Rasashastra \& Bhaishajya Kalpana, \\ 3. PG scholar Department of Dravyaguna, \\ Mahatma Gandhi Ayurved College Hospital \& Research Centre Salod (H) Wardha. India
}

\begin{abstract}
Background: Vidangadi Lepa is a classical herbo-mineral formulation explained by Chakradutta under Kushtha Chikitsa (skin diseases). Vidangadi Lepa is advised to be applied by mixing with cow's urine, which is not acceptable by many peoples, inconvenient and easily not available in the modern era. By keeping this in mind, in the present study an attempt has been made to prepare and analyze modified dosage forms of Vidangadi Lepa in the form of Vidangadi Lepaguti. Material and methods: Preparation of Lepaguti was done by triturating the powdered ingredients with cow's urine in three cycles. Consecutively three batches were prepared to nullify any inaccuracy during the pharmaceutical preparation. Analytical study was done to establish the basic standards for Vidangadi Lepaguti as there is no pharmacopeia standard guideline. The formulation was tested for organoleptic parameters, physicochemical analysis and microbial specification tests. Analysis of samples was conducted as per API standards. Observation and results: All the observations and results during preparation of Vidangadi Lepaguti regarding amount of liquid media required, time taken for each trituration cycle, weight gain after trituration and yield were noted down. The analytical tests performed over prepared samples i.e organoleptic, physicochemical and microbial specification were noted down in tabular form. Conclusion: Standard Vidangadi Lepaguti can be prepared from three Bhawana of Gomutra each for three hours. Prepared Vidangadi Lepaguti will be yellowish brown in color with specific smell of cow urine and average yield can be obtained by $94.28 \%$.
\end{abstract}

Key Words: Vidangadi, Lepaguti, Ayurvedic topical, Pharmaceutical evaluation.

\section{Introduction}

According to Ayurveda, every material of this universe can be used as medicine, use of these materials for treatment is from various points of view, and it may be either for Vyadhinasana (able to eradicate ailment) or Rasayana (rejuvenative). These can be characterized under three clusters based on their origin viz. Herbal, Animal and Mineral origin, but these materials are not used as they are, for these purposes various types of Samskaras (processes) are needed to be performed on them, to achieve the desirable internally administrable form of these substances.

Rasashastra and Bhaishajya Kalpana (Indian alchemy and pharmaceutic) is a separate branch of Ayurveda medicine preparation which maintains the basic principles of Ayurveda while formulating any preparation. The substance through which we can overcome the fear of the disease is called Bhaishajya (medicine). Kalpana is a method / process or a kind of modification or a plan of preparation of medicines.

\section{* Corresponding Author:}

\section{Mangesh Dhote}

PG scholar, Department of Rasashastra \& Bhaishajya

Kalpana, Mahatma Gandhi Ayurved College Hospital

\& Research Centre. Salod(H). Wardha. MS. India

Email Id: vaidhyashri.mangesh@gmail.com
Panchavidha Kashaya Kalpana (five basic preparations) are the Primary medicine preparations. The selection of basic preparation for treatment purpose depends on various factors like Roga (ailment) and Rogibala (patient stregth).(1) The use of these five basic preparation were very much limited due to its short shelf life, lack of proper protocol for testing and practice of this medicine become difficult. These factors are the responsible for development of the opinion, to build up new-formulations that can be prepared from the modification of the five basic preparations.

So we can say that, the secondary preparations are those preparations which are prepared after modification of five basic preparation. Lepa Kalpana (topical medicaments) is the secondary preparation of Kalka Kalpana (Bolus or paste preparation) which is one of the five basic preparations. Lepa preparations are the 'topical medicaments' meant for external application on the 'skin' or the mucosal membrane.(2) The drugs which have to be used as Lepa are made into a fine powder. Before use on body, it is mixed with some liquid media such as water, oil, cow's urine or cow's clarified butter and made into a soft paste

Vidangadi Lepa is such a classical herbomineral formulation explained by Chakradutta under Kushtha Chikitsa for the management of various skin diseases.(3) It is explained as topical medicament which should be applied along with Cow's urine. The 
ingredients of Vidangadi Lepa (4)are Vidanga (Embelia ribes Burm. F), Saindhav (Rock salt), Haritaki (Terminalia chebula Retz), Bakuchi (Psoralea corylifolia Linn.), Sarshapa (Brassica campestris Linn), Karanja (Pongamia pinnata Linn.Merr) and Haridra (Curcuma longa Linn.), fine powder of all in equal quantity.

Vidangadi Lepa is advised to be applied by mixing with cow's urine, which is not acceptable by many peoples, inconvenient and easily not available in the modern era.

There are references available regarding the preparation of Lepaguti in classical texts(5) and in previous researches (6) by triturating (Bhawana) the powdered ingredients into the liquid media advised. Bhawana helps transformation of the coarse powder into finer state by particle size reduction and impregnation of properties of Bhawana Dravya and homogenization leading to modification of properties of the end product. The significance of Bhawana process is that, a drug prepared by this method produce a maximum bioavailability with a small dose.(7) By keeping this reference in mind in the present study an attempt has been made to prepare and analyze modified dosage forms of Vidangadi Lepa in the form of Vidangadi Lepaguti. Hence present study was planned which may serve as primary source for further research on this topical dosage form.

\section{Material and Methods Material}

Present pharmaceutical study is designed to standardize the method of Vidangadi Lepaguti. For this purpose raw drugs (fig no.1) were procured from
Dattatraya Ayurveda Rasashala. As per organoleptic characters and API standards (Ayurvedic pharmacopoeia of India), it was authenticated from Department of Dravyaguna and Quality control laboratory, Dattatraya Ayurveda Rasashala Mahatma Gandhi Ayurved College \& Research Center Salod(H) Wardha respectively.

\section{Fig no.1: Raw ingredients of Vidangadi Lepaguti}

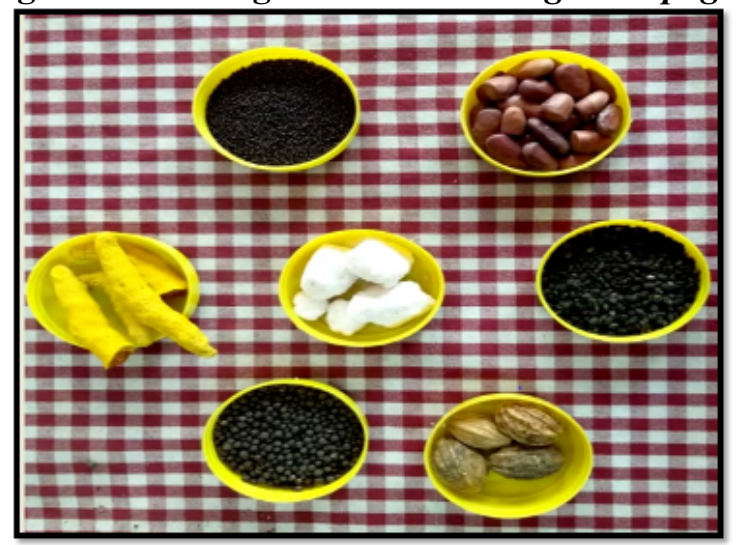

\section{Methods}

a) Preparation of Powdering of ingredients:

The powdering of ingredient drugs (table no.1) was done as per the Reference of AFI part II Churna Paribhasha Prakaran.(8) In the main pharmaceutical process of powdering firstly, all herbal material were cleaned physically to get rid of the unwanted particle. The drugs were kept in a tray and dried in sunlight, then dried and weighed. Pulverized to make it powder form. The powder was sieved with the help of mesh no.80. The sieved powder was measured and collected in an air tight container for further procedure.

Table No.1: Ingredients and Quantity of Vidangadi Lepa

\begin{tabular}{|l|l|l|l|l|l|} 
Sr. no & Ingredient & Scientific name & Part used & Raw Quantity & Obtained Quantity \\
\hline $\mathbf{1}$ & Vidanga & Embelia ribes Burm. F & Fruits & $200 \mathrm{gm}$ & $171 \mathrm{gm}$ \\
$\mathbf{2}$ & Saindhav & Sodii chloridum & - & $200 \mathrm{gm}$ & $192 \mathrm{gm}$ \\
$\mathbf{3}$ & Haritaki & Terminalia chebula Retz. & Pericarp & $250 \mathrm{gm}$ & $187 \mathrm{gm}$ \\
$\mathbf{4}$ & Bakuchi & Psoralea corylifolia Linn. & Seeds & $200 \mathrm{gm}$ & $175 \mathrm{gm}$ \\
$\mathbf{5}$ & Sarshapa & Brassica campestris var.sarson Prain & Seeds & $200 \mathrm{gm}$ & $158 \mathrm{gm}$ \\
$\mathbf{6}$ & Karanja & Pongamia pinnata Linn.Merr & Seeds & $200 \mathrm{gm}$ & $159 \mathrm{gm}$ \\
$\mathbf{7}$ & Haridra & Curcuma longa Linn. & Rhizome & $200 \mathrm{gm}$ & $179 \mathrm{gm}$
\end{tabular}

\section{b) Preparation of Vidangadi Lepaguti}

Equal quantity (50gm) of each powdered ingredient of Vidangadi Lepa was mixed with the help of spatula in a stainless steel vessel to prepare a homogenous mixture (fig no.2). This mixture was taken in Mortar and triturated with cow's urine (fig no.3). cow's urine was added in sufficient quantity so that it facilitates proper movement of pestle in mortar. Trituration was continued with the pestle till the liquid gets dried and material gets converted into semi solid mass. The semi-solid mass was transferred to Stainless steel tray and allowed to dry. After complete drying the material was shifted into mortar and again levigated with Gomutra. This whole process was repeated for 3 times. Lepaguti was prepared from bolus after the completion of $3^{\text {rd }}$ Bhawana. Lepaguti of uniform shape and size were prepared with the help of moulds and then it was kept for complete drying (fig no.4). Same way all the three batches were prepared to develop pharmaceutical standardization and named V1,V2 and V3. Lepaguti prepared was stored in air tight container and utilized for analytical study. 


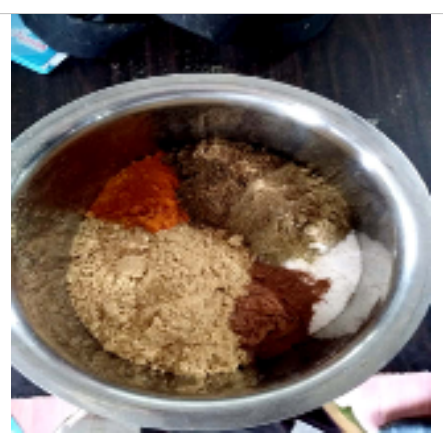

Fig.2: Mixing of powdered ingredients

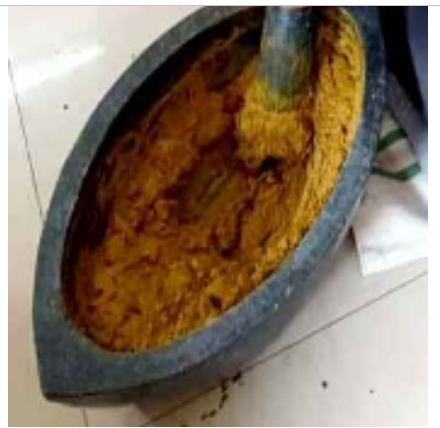

Fig.3: Trituration of

Vidangadi Lepa with cow's urine
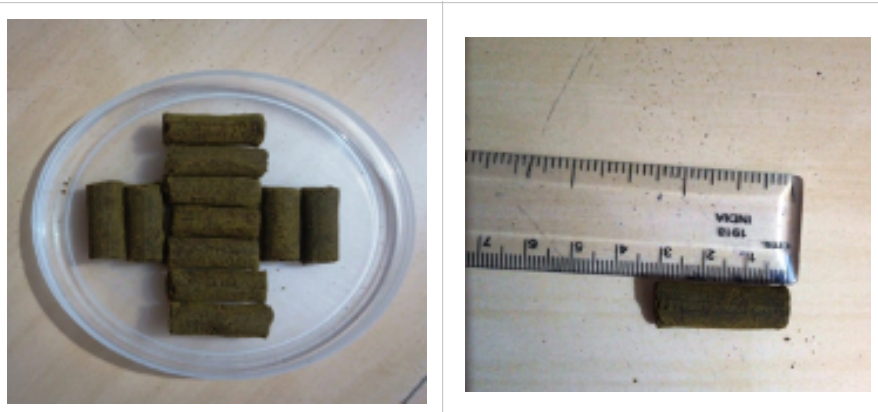

Fig.4: Prepared Vidangadi Lepaguti

\section{C) Analytical Study}

Analytical study was done to establish the basic standards for Vidangadi Lepaguti as there is no pharmacopeia standard guideline. The formulation was tested for organoleptic parameters, Physicochemical analysis and microbial specification tests. Analysis of samples were conducted as per API standards.

\section{Observation and results}

\section{A) Preparation of vidangadi Lepaguti}

Quantity of Gomutra and duration required for Bhawana decreased with subsequent Bhawana. Average quantity of Gomutra required for one Bhawana was $336.67 \mathrm{ml}$. Average required time duration for one Bhawana was $3 \mathrm{hr} 5 \mathrm{~min}$. Average weight gain was $93.33 \mathrm{gm}(27 \%)$ was found after the completion of $3^{\text {rd }}$ bhawana in wet mass. There was an average $94.28 \%$ yield was found while preparing after the complete drying of Vidangadi Lepaguti. Lepaguti with round shaped were prepared average weighing $2.8 \mathrm{gms}$ and each $3 \mathrm{~cm}$ in length. Observation and result during preparation of Vidangadi Lepaguti was noted down in tabular form (table no.2). Colour of ingredient powder was yellow which converted into brown shade in prepared Lepaguti. Lepagutis were having the smell of Gomutra

Table No. 2: Observation during preparation of Vidanagadi Lepaguti

\begin{tabular}{|c|c|c|c|c|c|c|c|c|}
\hline Batches & $\begin{array}{l}\text { Wt. of } \\
\text { Vidangadi } \\
\text { Lepa } \\
\text { churna } \\
\text { (gm) }\end{array}$ & $\begin{array}{l}\text { No.of } \\
\text { Bhawana }\end{array}$ & $\begin{array}{l}\text { Amount } \\
\text { of } \\
\text { Gomutra } \\
\text { required } \\
(\mathrm{ml})\end{array}$ & $\begin{array}{l}\text { Duration } \\
\text { of } \\
\text { Bhawana } \\
\text { (min) }\end{array}$ & $\begin{array}{l}W t \text { of wet } \\
\text { mass } \\
\text { after } 3^{\text {rd }} \\
\text { bhawana } \\
(\mathrm{gm})\end{array}$ & $\begin{array}{l}\text { Total } \\
\text { weight of } \\
\text { prepared } \\
\text { Guti after } \\
\text { drying } \\
\text { (gm) }\end{array}$ & Yield \% & Loss \% \\
\hline \multirow[t]{3}{*}{ V1 } & 350 & $1^{\mathrm{st}}$ & 430 & 210 & 437 & 330 & 94.28 & 5.71 \\
\hline & & $2^{\text {nd }}$ & 330 & 190 & & & & \\
\hline & & $3^{\text {rd }}$ & 220 & 160 & & & & \\
\hline \multirow[t]{3}{*}{ V2 } & 350 & $1^{\text {st }}$ & 440 & 200 & 436 & 324 & 92.57 & 7.42 \\
\hline & & $2^{\text {nd }}$ & 350 & 180 & & & & \\
\hline & & $3^{\text {rd }}$ & 250 & 180 & & & & \\
\hline \multirow{3}{*}{ V3 } & \multirow{3}{*}{350} & $1^{\text {st }}$ & 420 & 200 & \multirow{3}{*}{440} & \multirow{3}{*}{336} & \multirow{3}{*}{96} & \multirow{3}{*}{4} \\
\hline & & $2^{\text {nd }}$ & 360 & 190 & & & & \\
\hline & & $3^{\text {rd }}$ & 230 & 170 & & & & \\
\hline Avg & 350 & & 336.67 & 185.56 & 437.67 & 330 & 94.28 & 5.71 \\
\hline
\end{tabular}

\section{B) Analytical study}

The observation and results for analytical study were noted down in tabular fom. The formulation was first tested for organoleptic parameters such as touch, odor and color which are shown in table no.3. Physicochemical analysis includes loss on drying at $105^{\circ} \mathrm{C}$, Total ash, Acid insoluble ash, Alcohol soluble extractives, water soluble extractive and $\mathrm{pH}$. The observation and results for physicochemical tests are shown in table no.4 Microbial specifications were tested to validate its safety and therapeutic use. Table no.5 shows the results for microbial specification for Enteriobacteriaceae, Total fungus count, E-coli, Salmonella, Staphylococcus aureas and Pseudomonas aeruginosa which were performed as per CCRAS parameters. 
Mangesh Dhote et.al., Pharmaceutical evaluation of Vidangadi Lepaguti- an Ayurvedic topical formulation

Table no.3: Organoleptic parameters of Vidangadi Lepaguti

\begin{tabular}{|c|c|c|c|}
\hline Parameters & V1 & V2 & V3 \\
\hline Touch & Smooth & Smooth & Smooth \\
\hline Colour & Brown & Brown & Brown \\
\hline Odour & Characteristic & Characteristic & Characteristic \\
\hline
\end{tabular}

Table no.4: physicochemical parameters of Vidangadi Lepaguti

\begin{tabular}{|c|l|c|c|c|}
\hline Sr.no & \multicolumn{1}{|c|}{ Parameters } & V1 & V2 & V3 \\
\hline $\mathbf{1}$ & Loss on drying (\% W/W) & 5 & 5.3 & 5.06 \\
\hline $\mathbf{2}$ & Ash Value (\%w/w) & 18.1 & 18.5 & 19.2 \\
\hline $\mathbf{3}$ & Acid insoluble ash(\%w/w) & 2.31 & 2.29 & 2.31 \\
\hline $\mathbf{4}$ & Water soluble extract $(\% \mathrm{w} / \mathrm{w})$ & 31.38 & 30.72 & 30.88 \\
\hline $\mathbf{5}$ & Alcohol soluble extract $(\% \mathrm{w} / \mathrm{w})$ & 20.32 & 20.96 & 21.56 \\
\hline $\mathbf{6}$ & $\mathrm{pH}(\% \mathrm{w} / \mathrm{v})$ & 5.15 & 5.34 & 5.52 \\
\hline
\end{tabular}

Table no.5: Microbial contamination test of Vidangadi Lepaguti

\begin{tabular}{|c|l|l|l|l|}
\hline Sr.no & \multicolumn{1}{|c|}{ Parameters } & V 1 & V2 & A3 \\
\hline $\mathbf{1}$ & Total viable counts & Absent & Absent & Absent \\
\hline $\mathbf{2}$ & Enterobacteriaceae & Absent & Absent & Absent \\
\hline $\mathbf{3}$ & Total fungus counts & Absent & Absent & Absent \\
\hline $\mathbf{4}$ & E-coli & Absent & Absent & Absent \\
\hline $\mathbf{5}$ & Salmonella & Absent & Absent & Absent \\
\hline $\mathbf{6}$ & Staphylococcus aureus & Absent & Absent & Absent \\
\hline $\mathbf{7}$ & Pseudomonas aeruginosa & Absent & Absent & Absent \\
\hline
\end{tabular}

\section{Discussion}

Lepa Kalpana is a form of Kalka Kalpana (bolus or paste preparation). The purpose for which it is used decides its nomenclature. Lepa may be equated with paste or plaster, though these words are not competent to explain Lepa in all its aspects elaborately. Drugs in wet form are to be crushed to fine paste form. If the drugs in Lepa are in dry form then there powder should be converted into paste by adding specified amount of liquid. This paste is to be applied externally and is known as Lepa.(9) Herbal Lepa formulations preserve their potency up to two year if kept in an air tight containers.(10) Moreover there is a possibility of deterioration of powder if the powder is exposed to the moisture conditions. To overcome this problem, Lepa powder is modified into Lepaguti. Lepaguti were made by triturating the fine powders of the drugs with the liquids prescribed in the formula to form a soft paste. This was then made into solid, round, cylindrical shaped sticks of about $3 \mathrm{~cm}$ in length and dried in shade. Lepaguti can be preserved for three year if kept in air tight container(11) thus it is having the advantages of long shelf life, portability, fixed dosage forms and global acceptance.

In short we can say, Lepaguti is concept of potentiating the drug action by giving Bhawana (trituration) with respective liquid media. Acharya Sharangadhar has advocated the concept of Lepaguti (12), but did not use the term Lepaguti.

Bhawana or trituration process can be explained by Griffith theory. According to this theory, all solids contain flaws and microscopic cracks. Usually, the surfaces of particles are irregular. The applied force in the form of pressure is initially taken on high portion of the surface. As a result, high stress may be set up locally in the particles. The bond at this place becomes weak, which may be responsible for flaws. The particle with the weakest flaw fractures, produce largest possible pieces very easily. In the same way next particle develop another flaw. By this series of flaws and cracks particle size get reduced.(13)

In trituration process, the materials with liquid media are rubbed between the surface of pestle and mortar. This process involves breakdown of the material by rubbing action between two surfaces, i.e. surface phenomena, it is also called as attrition.(14) When stress in the form attrition is applied, and particle surfaces chip and produce small particles. Particle size and surface area of solid dosage form are inversely related to each other. As Particle size decreases and surface area increases, particles become random in position. When it comes in contact with liquid media, each molecule gets surrounded by liquid.

By these, impregnations of constituents of liquid media utilized for trituration into triturated drug becomes easier and enhances the rate of reaction. This can be explained by theory of collision.(15) According to this, reaction can occur only when reacting particle collide with each other. Larger the available surface area for particles to collide more will be the collision. As a result rate of reaction will increase. In this collision old bonds of compounds get broken and new bonds formed. With the formation of this new bond, properties of compound get changed or enhanced.(16)

During trituration process levigation of Vidangadi Lepa with cow's urine has been done, which not only yield combined effect but also produce a certain synergetic action. Particle size reduction by wet trituration increases the surface area of drug. All these things together not only makes it more bio-available but also helps in reducing the dose.

Amount of liquid used in trituration process may be understood by Capillary properties, which 
describes the processes of interaction of porous powder materials with the liquid. The porosity or pore volume of a material has been defined as the total proportion of air spaces contained between the solid particles of which the body is composed while permeability is restricted to interconnecting spaces.(17) When a dry porous medium, such as a brick or a wick is brought into contact with a liquid, it starts absorbing the liquid at a rate which decreases over time.(18) In all three batches of vidangadi Lepaguti i.e V1, V2 and V3 the average cow's urine required for first, second and third cycle for trituration was approx. $430 \mathrm{ml}, 346 \mathrm{ml}$ and $233 \mathrm{ml}$ respectively. This shows the decreasing amount of liquid media required during the subsequent cycles. Reason behind the decreased amount of liquid required can be elicited by reduced porosity of powder by process of trituration.

After the $3^{\text {rd }}$ cycle of trituration in the consecutively three batches the weight of wet mass was 437,436 and 440 for batches V1, V2 and V3 which finally after drying brings out the Lepaguti of $330 \mathrm{gm}$, $324 \mathrm{gm}$ and $336 \mathrm{gm}$ respectively. The loss during Lepaguti preparation was average $24.6 \%$ which may be due to loss of moisture content after drying and spillage during preparation of Lepaguti with the moulds. When the final product i.e Vidangadi Lepaguti was calculated with reference to raw powder utilized during the preparation, there was average $5.71 \%$ of loss found.

Loss on drying at $105^{\circ} \mathrm{C}$ indicates presence of moisture content. If moisture content is more than permissible limit then the formulation is more likely to get infected by fungal growth. Moreover unwanted changes can also occur due to presence of more moisture. In the prepared batches V1, V2 and V3 (average 5.12) moisture content is much less which means this formulation has more stability.

Acid insoluble ash represents presence of inorganic content which is not expected in herbal formulation. The obtained value of Acid insoluble ash in the batches V1, V2 and V3 are 2.31, 2.29 and 2.31 respectively which seems to be negligible. Insignificant difference is observed in water soluble extractives which may be due to trituration with cow's urine. Alcohol soluble extractive value is also nearly same in all three batches.

The $\mathrm{pH}$ of $\mathrm{V} 1, \mathrm{~V} 2$ and $\mathrm{V} 3$ are found to be 5.15,5.34 and 5.52 respectively. Our skin has a thin, protective layer on its surface, referred to as the acid mantle. This acid mantle is made up of sebum excreted from the skin's sebaceous glands, which mixes with lactic and amino acids from sweat to create the skin's pH.(19) The skin $\mathrm{pH}$ is between 4.5 to 6.2 , slightly acidic. $(20,21)$ If the drug is too alkaline or too acidic it breaks the acid mantle and results in various skin problems. The $\mathrm{pH}$ of samples indicating it is not harmful for the application on skin as it maintains the acid mantle of the skin shows the suitability of samples for local application.

The Microbial load test of final preparation for all batches were observed and found no growth. During the preparation proper precautions were taken to avoid any contamination.
The pharmaceutical standards for Vidangadi Lepaguti are not available hence the analytical results of present study may prove exposure towards establishing analytical standards for Vidangadi Lepaguti.

\section{Conclusion}

Standard Vidangadi Lepaguti can be prepared from three Bhawana of Gomutra each for three hours. Prepared Vidangadi Lepaguti will be brown in color with specific smell of cow urine and average yield of $94.28 \%$ can be obtained. Analytical findings of present study can be considered as reference standard for Vidangadi Lepaguti. Lepaguti can be a better option for Lepa as it gives more stable, more potentiated and easy to administrable unit dosage form.

\section{References}

1. Charaka Samhita of Agnivesh, Shashtri K (editor) Sutrasthana 4/7, Chaukhambha Sanskrit SansthanVaranasi,reprint edition, 2006,69p

2. Angadi R. Bhaisajya Kalpana Vijnana. Varanasi; Chaukhamba Surbharati Prakashan;2016,349p

3. Sharma P V. Cakradutta. Reprint edition. Delhi;Chaukhamba Orientalia;2007,391p

4. Sharma P V. Cakradutta. Reprint edition. Delhi;Chaukhamba Orientalia;2007,391p

5. Sharangadhar Samhita of Sharangadhar, Shastri P(editor)Uttara Khanada11/1 Choukhamba Orientalia Varanasi, $6^{\text {th }}$ edition, $2005,18 p$

6. Rathi B, Rathi R, Rajput DS. Pharmaceutical standardization of Avalgujadi Lepaguti. J Indian Sys Med 2016;4(2);72-76

7. Rathi B and Rathi R. Pharmaceutical Standardization of Bakuchi vati- A modified dosage form of Dhatryadi Yoga,Int. J. Res. Ayurveda Pharm,2017;8(1):57-61

8. Anonymous, The Ayurvedic Formulary of India First Edi. The Ministry of Health and Family Welfare, Dept. of Indian systems of Medicine \& Homoeopathy, 2000, Part II, Churna Paribhasha Prakaran, New Delhi.

9. Sharma PV Dravyaguna vigyanam 2/105 first edition. New Delhi ; chaukhamba orientalia; 2002.6p.

10. Anonymous , Ministry of Ayurveda, Yoga and Naturopathy, Unani, Siddha and Homoeopathy (AYUSH),Drug and cosmetic rule 2016, annexure I, rule 161-B. Shelf life or date of expiry of medicines ;2016.17p.

11. Anonymous, Ministry of Ayurveda, Yoga and Naturopathy, Unani, Siddha and Homoeopathy (AYUSH),Drug and cosmetic rule 2016, annexure I, rule 161-B. Shelf life or date of expiry of medicines.;2016. 17p.

12. Sharangadhar Samhita of Sharangadhar, Shastri P(editor)Uttara Khanada11/1 Choukhamba Orientalia Varanasi, $6^{\text {th }}$ edition, $2005,18 p$

13. Griffith AA. The phenomena of rupture and flow in solids, Philosophical Transactions of the Royal Society of London. Series A, Containing Papers of a Mathematical or Physical Character.1921. 163p. 
14. Available from: http://dictionary.reference.com/ browse/attrition accesed on dated 12-04-2020 time 19:08 IST.

15. Available from: http://www.adichemistry.com/ physical/kinetics/collision/collision-theorykinetics.html accesed on dated 12-04-2020 time 19:50 IST.

16. Available from: http://www.adichemistry.com/ physical/kinetics/collision/collision-theorykinetics.html accesed on dated 12-04-2020 time 19:05 IST.

17. Available from: https://www.sciencebuddies.org/ science-fair-projects/project-ideas/Geo_p012/ geology/porosity-and-particle-size accesed on dated 12-04-2020 time 20:06 IST .

18. Available from: https://en.wikipedia.org/wiki/ Capillary action accesed on dated 13-04-2020 time 15:20 IST.

19. Schmid-Wendtner MH, Korting HC. pH and Skin Care. ABW Wissens chaftsverlag. 2007.31p

20. Zlotogorski A. Distribution of skin surface $\mathrm{pH}$ on the forehead and cheek of adults. Arch. Dermatol. Res. 1987;279(6):398.

21. Schmid MH, Korting HC. The concept of the acid mantle of the skin: its relevance for the choice of skin cleansers. Dermatology. 1995; 191 (4): 276. 